\title{
Gas-Flaring Practice in Nigeria and its Impacts on Global Warming: Need for Immediate Government Intervention
}

\author{
Ezeozue, Chidozie \\ Department of Political Science, Chukwuemeka Odumegwu Ojukwu University, \\ Igbariam Campus, Anambra State, Nigeria
}

\begin{abstract}
How to cite this paper: Ezeozue, Chidozie "Gas-Flaring Practice in Nigeria and its Impacts on Global Warming: Need for Immediate Government Intervention" Published in International Journal of Trend in Scientific Research and Development (ijtsrd), ISSN: 24566470, Volume-3 | Issue-4, June 2019, pp.1013-1018, URL: https://www.ijtsrd.c om/papers/ijtsrd24 046.pdf

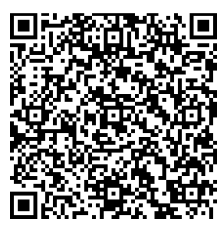

IITSRD24046
\end{abstract}

Copyright (C) 2019 by author(s) and International Journal of Trend in Scientific Research and Development Journal. This is an Open Access article distributed under the terms of the Creative Commons

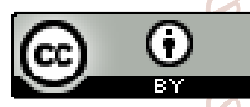
Attribution License (CC BY 4.0) (http://creativecommons.org/licenses/ by/4.0)

This is caused primarily by increases in greenhouse gases such as carbon dioxide (CO2). Recently, and especially over the past three or four decades, the issue of global climate change due to the greenhouse effects, including global warming and sea level rise have been a subject of scientific discussions and public debate (Shehu, Auwal \& Dahuwa, 2018; Olufemi \& Samson, 2012). With our natural sense organs, we can observe this. In fact, the biosphere (the earth's ecological system) that supports life-its land, water, air and upper atmosphere - and living organisms, inhabiting it, human beings inclusive are under severe threat. Among all creatures, human beings are the ones imbued with intelligence and the capability to alter the ecosystem positively or negatively. Activities of human beings at individual and group levels including corporations and governments are causing grievous ruins in the ecosystem. The damage being caused by human beings to ecosystem may be unintended. They are consequences of actions of human beings at various levels. One obvious fact is that activities of human beings are causing havoc on the ecosystem with grievous consequences, whether intended or unintended. Gas flaring is one of the numerous ways human beings are gradually warming the globe. The warming is done by emitting carbon dioxide $\left(\mathrm{CO}_{2}\right)$ and other gases, especially methane and chlorofluoro-carbons (CFCs) into the upper atmosphere where they accumulate and create a blanket effect, trapping heat and preventing the nightly cooling of the Earth. Warmer days follow reduced cooling, resulting in what is termed the greenhouse effect based on the way an agricultural greenhouse accumulates heat by allowing incoming solar radiation but obstructing the outward flow of heat. A World Bank sponsored study (1995) defined gas flaring as "wasteful emission of greenhouse gases that causes global warming." According to the Organization of Petroleum Exporting Countries, OPEC (2012) 'Releasing gas ignited into the atmosphere is called venting; igniting it as it is released is called flaring.'

Gas flaring is the burning of natural gas that is associated with crude oil when it is pumped up from the ground. Natural gas flaring has become a major source of greenhouse gas (GHG) emissions that has proven intractable to curtail around the world. Gas flaring in this context is the burning of natural gas associated with oil and gas production (Odionu, 2018). In petroleum-producing areas where insufficient investment was made in infrastructure to utilize natural gas, flaring is employed to dispose of this associated gas (Justice in Nigeria Now, April, 2010). Wikipedia in "Gas Flare" stated that a gas flare, alternatively known as a flare stack, is gas combustion device used in industrial plants such as petroleum refineries, chemical plants, natural gas processing plants as well as at oil or gas production sites having oil wells, gas wells, offshore oil and gas rigs and land fills. In 
what appeared to be a correction of its 2007 edition to the effect that "they (gas flares) are used to eliminate waste gas which is otherwise not feasible to use or transport", the 2011 edition went further to state that "in areas of the world lacking pipelines and other gas transportation infrastructure, vast amount of such associated gas are commonly flared as waste and unusable gas. Such flaring constitutes a hazard to human health and also significantly contributes to the world-wide anthropogenic emissions of carbon dioxide $\left(\mathrm{CO}_{2}\right)$ and other gases, including methane and chlorofluorocarbons, which have greatly induced the depletion of the ozone layer which has in turn contributed to global warming.

\section{Gas Flaring in Nigeria}

Natural gas flaring is one of the most damaging practices in the Nigerian petroleum industry and this has continued to give rise to unimaginable complex consequences in the Niger Delta region of Nigeria, with regard to human health and natural environment. Nigeria's volume of gas flaring is among the highest in the world and only few countries are ahead in terms of billion cubic meters (bcm) of gas flared yearly (Odionu, 2018). It has been said that more gas is flared in Nigeria than anywhere in the world (Climate justice Programme (CJP). CJP went on to state that the gas industry statistic publisher, Cedipaz, indicates that Nigeria accounted for $19.79 \%$ of global flaring in 2001, more than the second (Iran) and third (Indonesia) countries combined. However the Organization of Petroleum Exporting Countries (OPEC) report published in it's February 2012 bulletin ranked Nigeria as the second highest gas flaring country in the world. The report stated: "Nigeria, a GGFR (Global Gas Flaring Reduction partnership) member from the start in 2002, has been attempting to set solid deadlines for the elimination of flaring for some time. Admittedly, domestic flaring volumes having fallen by one-third between 2004 and 2010, but the nation still remains the second-largest gas flaring country, with volumes of $15.2 \mathrm{bcn}$ in 2010,11 percent of the world total."

"Unfortunately, the large-scale projects that the government had hoped to implement to minimize flaring have prove to be more difficult to put into practice than was anticipated. They include the West Africa Gas pipeline, which faced years of delay, growing number of proposed LNG (Liquefied Natural Gas) projects, most of which have yet to get off the drawing board and the Escarvos GTL plant, which has suffered long delays and massive cost over-runs." The simple reason why the projects hoped to implement to minimize flaring had not worked is that Government lacks the political will and the determination to stop gas flaring. Environmental Rights Action, ERA, (2008) had stated that there are over 100 flare sites still emitting a toxic cocktail of chemical into the atmosphere in Niger Delta, South-South Nigeria. Through this obnoxious and harmful act, the country has lost about $\$ 72$ billion in revenues for the period 1970-2006 or about $\$ 2.5$ billion annually. All these go up in smoke yearly polluting the air, leaving destructions in many spheres, human lives, agricultural products and the ozone layer which in turn brings about climate change and global warming.

The practice of gas flaring was recognized as objectionable right from the colonial days. An admission of this fact could be seen in archival documents from the pre-independence day. Factually, the Secretary of States for Colonies was in 1958 asked whether they (the British people) would not be blamed for wastage of energy and resources through gas flaring in Nigeria. That this nagging issue did not end with casual pre-independence queries could be ascertained from the rather patronizing 1963 confidential communication to the UK Foreign office from the them British Trade Commissioner: "Shell/BP's need to continue, probably indefinitely to flare off a very large proportion of the associated gas they produce will no doubt give to certain amount of difficulty with Nigerian politicians, who will probably be among the last people in the world to realize that it is sometimes desirable not to exploit a country's natural resources and who, being unable to avoid seeing the many gas flares around the oilfields, will tend to accuse Shell/BP of conspicuous waste of Nigeria's 'wealth'. It will be interesting to see the extent to which the oil companies feel it necessary to meet these criticism by spending money on economic methods of using gas." "In the longer run, Shell/BP is going to have to consider very carefully how it should explain publicly the large outflow of capital that is likely to take place towards the end of the decade....it will not doubt come as something of shock to Nigerians when they find that the company is remitting large sums of money to Europe. The company will have to counter the criticisms which will very probably be made to the effect that the company is 'exploiting' Nigeria by stressing the very large contribution it is making to Nigeria's export earning" (Quoted in ERA/CJP Document, 2005).

\section{Record of Unkept Deadlines}

Since 1960 Nigeria gained independence, successive Governments of the country have not been serious, in fact, have been insincere with ending gas flaring, it's concomitant harmful effects notwithstanding. Deadlines towards ending the wasteful and harmful gas flaring have been shifted umpteen times. Unserious and insincere efforts towards ending the obnoxious gas flaring could be traced back to 1969 when the military Government led by General Yakubu Gowon ordered oil companies operating in Nigeria to work towards ending gas flaring in 1974. The 1974 deadline was not achieved as a result of the oil firm decision not to put in place gas utilization facilities, making the then military government to extend the deadline to 1979. The aspiration of Nigerians to effectively utilize the huge gas resources was dashed in 1979 when the multinational oil firms failed to meet the deadline. This compelled the civilian government of Shehu Shagari to enact, the Associated Gas Re-injection Act of 1979, which outlawed the routine gas flaring with 1984 as the deadline. Section 3 of the Act titled "Flaring of gas to cease" stipulated that: (1) subject to subsection (2) of the section, no company engaged in the production of oil or gas shall after 1 January, 1984 flare gas produced in association with oil without the permission in writing of the Minister.

However, with Subsection 2 of that section (Section 3(2)), the effectiveness of the Act was compromised. It stipulated: where the minister is satisfied after 1 January, 1984 that utilization or re-injection of the produced gas is not appropriate or feasible in a particular field or fields, he may issue a certificate in respect to a company engaged in the production of oil or gas -

1. Specifying such terms and conditions, as he may at his discretion choose to impose for the continued flaring of gas in the particular field or fields; or

2. Permitting the company to continue to flare gas in the particular field or fields if the company pays such sum as the Minister may from time to time prescribe for every 28.317 standard cubc metre (SCM) of gas flared. 
With the insertion of Section 3(2) in the Nigeria's Associated Gas Re-Injection Act, unending shifting of targets of gas flaring in Nigeria was guaranteed, notwithstanding the title of Section 3 "Flaring of gas to Cease", as loopholes to continue gas flaring unendingly was created. The 1984 deadline obviously was not met. As usual, excuses were given by multinational oil firms for not meeting the 1984 deadline. The practice of gas flaring continued, during the period of succeeding military regimes, though outlawed in principle from 1984.

With the coming in of a civilian administration in 1999, many Nigerians heaved a sign of relieve when President Olusegun Obasanjo's administration started a new gas flaring phaseout in 2000 and December 2003 was set as deadline for ending gas flaring, with its renewed investment in the Nigeria Liquefied Natural Gas (NLNG). But the oil firms preferred 2006 as the most realistic date to end gas flaring. Both parties later reached agreement to end gas flaring by the end of 2004. However, the Nigerian government later pushed the date further by two years to 2006 as had requested by the multinational oil firms. The 2006 deadline as usual was not met and as the deadlines are never respected, various Nigerian Governments have weakly and corruptly, resorted to shifting them according to the whims and caprices of the multinational oil firms through executive orders embedded in speeches and without any law backing such actions.

In response to local and international pressures the Nigerian Government once again pledged to stop gas flaring in the country with $1^{\text {st }}$ January 2008 as the deadline. This as usual was not to be because by December 17,2007 , a shift on the deadline was announced with $31^{\text {st }}$ December, 2008 as the new target date. That announcement generated a lot of heat in Nigeria and the National Assembly felt the need to do something as the Executive arm of government tended to lack the strong will and the determination to halt gas flaring in the country. The Assembly embarked on the drafting of a Bill to end the obnoxious gas flaring by $31^{\text {st }}$ December 2008. However, the Bill tended to be in the cooler ever since as gas is still being flared in the country, sending poisonous substances into the atmosphere that contribute to global warming. Again, there was another deadline with $31^{\text {st }}$ December 2010 as the target, this as usual was not met. Now the newly drafted oil Bill, which is close to being finalized requires that oil firms must cease flaring gas by $31^{\text {st }}$ December 2012, and that if they don't, they will be fined. This target has been seen by many as unrealistic. We are already in June and the processes the bill has to undergo before it is signed into law has not been completed.

\section{Quatum of Gas Being Flared by Nigeria}

Different figures have been quoted as the volume of gas flared by Nigeria over the years. Under a subheading titled 'Global impacts from flaring and how Nigeria stacks up' Justice in Nigeria Now, JINN, (2010) stated that Nigeria, the second largest offending country, after Russia, in terms of the total volume of gas flared, on the average was responsible for 24.1 billion cubic meters (BCM) annually of gas flared in the world for the period 1996 - 2006 (By comparism the U.S. flared 2.8 BCM during the period) see figure I showing year 2004 BCM Estimates.

\section{Figure I}

\section{Year 2004 BCM Estimates}

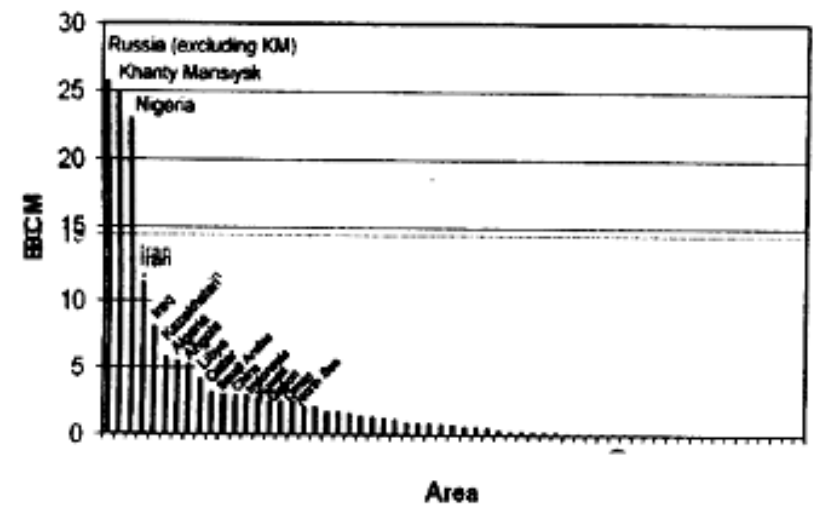

"A Twelve Year Record of National and Global Gas Flaring Volumes Estimated Using Satellite Data," Final Report to the World Bank, May 30, 23907, Figure 13 , gvailable at http://siteresources.woridbank.org/INTGGFR/R esources/DMSP flares 20070530 b-sm.pdf

The online Monthly Petroleum Information (MPI) for May 2012 of the Nigerian National Petroleum Corporation (NNPC) claimed the volume of gas flaring in the country has dropped from 19 percent in December 2011 to 14 per cent in January 2012. The Corporation attributed the drop to increased use of gas for power generation, export and industrial applications. It said that out of 215.84 billion Standard Cubic Feet (bscf) of gas produced in January, 199.41 bscf was effectively utilized. NNPC said only 30.16 bscf or 3.97 per cent of the total gas produced was flared at both the onshore and offshore oil fields, in the month under review. According to the publication, Shell Petroleum Development Company (SPDC) led the gas production chart with $76.4 \mathrm{bscf}$ with only $5.94 \mathrm{bscf}$ of the gas flared. Mobil Producing Nigeria Unlimited followed with the flaring of $9.85 \mathrm{bscf}$ of gas from 38.63bscf of gas produced (NNPC, 21 May 2012).

In what looked like correcting the wrong information given by NNPC as regard the rate of gas being flared by Nigeria, the Department of Petroleum Resources, DPR, directly concerned with the production of petroleum in Nigeria had stated that about 24 percent of Nigerian gas is still being flared. Its Director Mr. Osten Olorunsola, confirmed this in June 2012 as was carried by a Nigerian Newspaper, the Punch on $13^{\text {th }}$ June 2012 . While that figure is at least 10 percent more than the one earlier quoted by the parent body, NNPC, keen watchers of the Nigerian petroleum industrial activities are of the view that the percentage of gas actually flared is more than the $24 \%$ of the total production as stated by the DPR. Thus, Ayoola (2011) stated that "out of the $5.78 \mathrm{~mm}$ cf of gas produced per day, $80 \%$ of it is flared while $12 \%$ is re-injected to enhance oil production. This leaves the nation utilizing only about $80 \%$ of its produced gas for both domestic and industrial uses as well as for export." 


\begin{tabular}{|c|c|c|c|c|c|c|c|}
\hline Ranking & Country & 2006 & 2007 & 2008 & 2009 & 2010 & $\begin{array}{r}\text { Ehangige } \\
2009 / 10\end{array}$ \\
\hline 1 & Russia & 50.0 & 52.3 & 42.0 & 46.6 & 35.2 & -11.4 \\
\hline 2 & Nigeria & 18.6 & 16.3 & 15.5 & 14.9 & 15.2 & 0.3 \\
\hline 3 & Iran & 12.2 & 10.7 & 10.8 & 10.9 & 11.3 & 0.4 \\
\hline 4 & traq & 7.2 & 6.7 & 7.1 & 8.1 & 9.1 & 1.1 \\
\hline 5 & Algeria & 6.4 & 8,6 & 6.2 & A9 & 5.4. & 0,5 \\
\hline 6 & Angela & $4: 6$ & 3,5 & 3.5 & 9-4 & 4.1 & 0.7 \\
\hline 7 & Kazakhstan & 6.2 & 5.5 & 5.4 & 5.0 & 3.8 & -1.2 \\
\hline 8 & Libya & 4.4 & 3.8 & 4.0 & 3.5 & 3.8 & 0.3 \\
\hline 9 & Saudi Arabia & 4.2 & 4.2 & 4.3 & 3.9 & 3.7 & -0.2 \\
\hline 10 & Venezuela & 2.1 & 2.2 & 2.7 & 2.8 & 2.8 & 0.0 \\
\hline 11 & Mexico & 2.1 & 2.7 & 3.6 & 3.0 & 2.5 & -0.5 \\
\hline 12 & Indonesía & 3.2 & 2.6 & 2.5 & 2.9 & 2.3 & -0.6 \\
\hline 13 & China & 2.9 & 2.6 & 2.5 & 2.4 & 2.1 & -0.3 \\
\hline 14 & Canada & 1.7 & 2.0 & 1.9 & 1.8 & 2.1 & 0.3 \\
\hline 15 & USA' & 2.0 & 2.1 & 2.3 & 2.0 & 2.1 & 0.1 \\
\hline 16 & Uzbekistan & 2.9 & 2.1 & 2.7 & 1.7 & 1.9 & 0.2 \\
\hline 17 & Qatar & 2,3 & 12.4 & 2.3 & 2.2 & 1.9 & -0.3 \\
\hline 18 & Oman & 2.3 & 2.0 & 2.0 & 1.9 & 1.8 & -0.1 \\
\hline 19 & Malaysia & 1.9 & 1.8 & 1.9 & 1.9 & 1.5 & -0.4 \\
\hline 20 & Esypt & 1.7 & 1.5 & 1.6 & 1.8 & 1.5 & -0.3 \\
\hline \multicolumn{2}{|c|}{ Totittor $x=$} & 198 & 83 & 125 & 125 & 184 & $11 \%$ \\
\hline \multicolumn{2}{|c|}{ 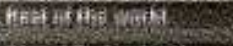 } & 49 & tit & 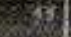 & 15 & 30 & 12 \\
\hline \multicolumn{2}{|c|}{ Global uaring level } & 162 & 154 & 140 & 297 & (12) & -128 \\
\hline
\end{tabular}

Source: US Notiond Oceonic and Atmospheric Administrotion (NOM) satellite dotu. - Coneroge limited ta Guif of Mexica, Alaska, and portidi continentol USA.

The Organization of Petroleum Exporting Countries (OPEC) ranked Nigeria as second largest gas flarer in the world with a total of 15.2 billion cubic waters (bcm) in 2010. (See Table 1) in terms of "flaring intensity" - defined as the amount of gas flared for each barrel of oil produced, Nigeria (17.34) is again second in the world, coming after Uzbekistan (59.83). When its is considered that the quantity of oil produced by Uzbekistan which is 32 million barrels per day in 2010 compared with that of Nigeria which is 877 million barrels per day also in 2010, th intensity of gas flared Uzbekistan becomes significant. See (table II).

\begin{tabular}{|c|c|c|c|c|c|c|c|c|c|}
\hline & $\begin{array}{l}2006 \\
(\mathrm{~cm})\end{array}$ & $\begin{array}{l}2010 \\
\text { (Bcm) }\end{array}$ & $\begin{array}{c}\text { \% change } \\
\text { (2010 over } \\
2006)\end{array}$ & $\begin{array}{c}\text { \% of world } \\
\text { total gas } \\
\text { flared in } \\
2010\end{array}$ & $\begin{array}{l}\text { Rasking } \\
\text { in G6FP's } \\
\text { list of top } \\
\text { gas-flariag } \\
\text { nations in } \\
2010\end{array}$ & $\begin{array}{l}2010 \text { oil } \\
\text { production } \\
\text { (milition b/at }\end{array}$ & $\begin{array}{l}2010 \text { ofl } \\
\text { production } \\
\text { (million } \\
\text { borreks) }\end{array}$ & $\begin{array}{l}2010 \text { gas } \\
\text { flaring } \\
\text { intensity } \\
\text { fcubic } \\
\text { metres/ } \\
\text { borre) }\end{array}$ & $\begin{array}{c}\text { cumulative } \\
\text { \% of world } \\
\text { total gas } \\
\text { flared in } \\
2010\end{array}$ \\
\hline Rassia & 50.0 & 35.2 & -30 & 26 & 1 & 10.27 & 3,749 & 9.39 & 26 \\
\hline Nizzeria & 18.6 & 15.2 & -18 & 11 & 2 & 2.40 & 877 & 17.34 & 38 \\
\hline Iran & 12.2 & 11.3 & -7 & 8 & 3 & 4.25 & 1,549 & 7.29 & 46 \\
\hline Iraq & 7.2 & 9.1 & 26 & 7 & 4 & 2.46 & 898 & 10.13 & 53 \\
\hline Algeria & 6.4 & 5.6 & -16 & 4 & 5 & 1.81 & 660 & 8.18 & 57. \\
\hline Angola & 4.0 & 4.1 & 2 & 3 & 6 & 1.85 & 676 & 6.07 & 60 \\
\hline Kazakhstan & 6.2 & 38 & -39 & 3 & 7 & 1.76 & 641 & 5.93 & 63 \\
\hline tibya & 4.4 & 3.8 & -14 & 3 & $B$ & 1.66 & 606 & 6.28 & 66 \\
\hline Sxudi Arabia & 4.2 & 3.7 & -12 & 3 & 9 & 10.07 & 3,676 & 1.01 & 68 \\
\hline Venezuela & 2.1 & 28 & 33 & 2 & 10 & 2.47 & 902 & 3.10 & 70 \\
\hline Maico & 2.1 & 2.5 & 19 & 2 & 11 & 2,96 & 1.080 & 2.32 & 72 \\
\hline Indonesia & 3.2 & 2.3 & -28 & 2 & 12 & 0.99 & 360 & 6.39 & 20 \\
\hline China & 2.9 & 2.1 & -28 & 2 & 13 & 4.07 & 1.486 & 1.41 & 76 \\
\hline Casada & 1.7 & 2.1 & 24 & 2 & 14 & 3,34 & 1,218 & $1, n$ & $n$ \\
\hline USA: & 2.0 & 2.1 & 5 & 2 & 15 & 7.51 & 2,742 & $a n$ & 79 \\
\hline Uzbekistan & 2.9 & 1.9 & -34 & 1 & 16 & 0.09 & 32 & 59.83 & 80 \\
\hline vacat & 2.3 & 19 & -17 & 1 & 17 & 1.57 & 573 & 3.32 & 82 \\
\hline Oman & 2.3 & 1.8 & -22 & 1 & 18 & 0.87 & 316 & 5.70 & 83 \\
\hline Malaysia. & 1.9 & 15 & -21 & 1 & 19 & 0.72 & 261 & 5.74 & 84 \\
\hline Egypt & 1.7 & 1.5 & -12 & 1 & 20 & 0.76 & 269 & 5.58 & 85 \\
\hline Total $=$ top 20 & 138 & 114 & -17 & 85 & & 61.8 & 22.568 & 5.06 & \\
\hline Fotal works & 162 & 134 & -17 & 100 & $E r$ & 29.9 & 29.181 & 4.59 & \\
\hline
\end{tabular}

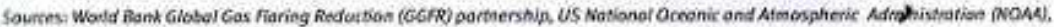
AP Stapisticol Anewiew of Worlo Energy 20 sa

- Coveroge linited to Gulf of Herica, Alasko, and partial contiontol usa. 


\section{Reasons for Flaring Gas in Nigeria}

There are several ways in which gas being flared could have been profitably used, yet it is continuously flared. Earlier, the general reasons for continuously flaring of gas have been stated, including, being used to for burning off flammable gas released by pressure relief valves during unplanned overpressuring of plant equipment, during plant start ups or partial shut downs for the planned combustion of gases over relatively short periods. However, a great deal of gas flared at many oil and gas production sites has nothing to do with protection against the dangers of over-pressuring industrial equipment. The flaring in Nigeria is a typical example. Thus various reasons have been given for continuously flaring of gas in Nigeria. Included are the lack of the necessary technology for gathering and conserving the gas flared, lack of market for the gas, the claim that the locations are too inaccessible and that the flaring can only end in some locations by shutting down production. Recently, the Shell Petroleum Development Company (SPDC) has shifted the blame to funding problems, asserting that the NNPC has defaulted in paying its part (55\% equity in the joint venture (JV) as causing delays in executing the gas flaring phase out plan.

Needless to say that some of the reasons are spurious, otherwise how can the SPDC which is the technical advisor of the Nigerian Liquefied Natural Gas (NLNG) joint venture agreement as well as the operator of the JV involving NNPC, which actually holds $55 \%$ of the JV claim that the NNPC is defaulting. The whole thing boils down to what has been said earlier that there is a conspiracy/connivance between the Nigerian Government (including her agencies) and the multinational oil companies. Once personal benefits are received by those authorized to take actions that will lead to end of gas flaring, the general or public interests are overlooked.

\section{Effects/Impacts of Gas Flaring}

It is an undeniable fact that exploration and exploitation of oil and gas resources has economic gains for every country. It provides a strong base for wealth creation as well as building a sustained economy. Contrary to the economic gains, there are negative consequences associated with crude oil extraction where it is not well managed (Nii, 2015; Amorin and Broni-Bediako 2013). Environmental pollution arising from gas flaring has impacted the biodiversity of host communities. The main stresses relative to oil and gas operations arise from gas flaring, leakages of crude oil, and the escape of other chemicals used in production processes (Ito \& Ugbome, 2017). The impacts of gas flaring are numerous. Locally, it pollutes the air across a wide area, effecting living organisms within the area adversely. Additionally, it causes global warming, disequilibrium of the earth, unprecedented weather changes and many natural disasters, consequent upon emission of benzene and other toxic substances that are harmful to humans, animals, plants and the entire physical environment. The impact of gas flaring and the attendant climate change debate has moved from being an illusion to being a serious environmental challenge for modern governments especially in developing societies. Even though, countries in the Global North have been the culprit and those in the Global South have been the victims, trading blames back and forth will only aggravate the damage already done. It is imperative that we face frontally the anthropogenic factors that have triggered the crisis in Nigeria (Urim, Imhonopi \& Egharevba, 2013).

\section{CONCLUSION}

Gas flaring brings about emission of poisonous gases to the atmosphere which in turn lead to climate change and global warming. The emitted toxic substances are harmful to human beings, animals, plants and the entire physical environment. As the second largest flarer in the world, Nigeria contributes substantially to global warming. Global warming must not be allowed to run its full course. Otherwise, the existence of living organisms, including man is not assured. The recommendations below implemented will contribute in no small measures in the overall effort to addressing of climate change and global warming.

\section{RECOMMENDATIONS}

To completely stop or at least reduce to the barest minimum, gas flaring in Nigeria, the following are recommended.

Firstly, Government of Nigeria shall ensure that all the international environment treaties and agreements are complied with by all concerned within the country, including the 1997 Kyoto Protocol, World Bank Global Gas Flaring Reduction (GGFR) Public-Private Partnership, 2002, and 2007 Bali Climate Declaration by Scientists.

Secondly, that all the Nigerian enactments concerning elimination of gas flaring are implemented to the letter. Sections of any Act that created loopholes for easy manipulations by corrupt officials shall be expunged.

Thirdly, Nigeria should diversify her sources of income. Reliance on oil money for over $90 \%$ of her income is injurious. It makes the country easy to be manipulated by the multinational oil companies that dominate production of petroleum in the country. In this regard, reference will be made to the views of AL-Bashir carried in a Nigerian Newspaper, Sunday Sun, $3^{\text {rd }}$ June 2012, to the effect that the World Bank Statistics has it that "Nigeria can earn three times from solid minerals, what it is earning from oil...that Nigerian can earn five times from agriculture what it can earn from oil."

Fourthly, with diversified economy, all oil wells where gas must be flared in order to produce petroleum, should be completely shut down. In the memo, of the Colonial Trade Commissioner earlier quoted, where he insulted the intelligence of Nigerian politicians, he had stated that "it is sometimes desirable not to exploit a country's natural resources".

Fifthly, all those large-scale projects the government hoped to implement to minimize flaring should be implemented without further delay.

\section{REFERENCES}

[1] Al-Bashir, A., "South-South does not produce oil" in Sunday Sun, June $3^{\text {rd }} 2012$.

[2] Audu, E. B. (2013). Gas Flaring: A Catalyst to Global Warming in Nigeria. International Journal of Science and Technology, 3 (1), 6-10.

[3] Ayoola, T.J. (2011). "Gas Flaring and its implication for Environmental Accounting in Nigeria" in Journal of Sustainable Development, 4(5); October 2011, www.ccsenet.org/jsd. 
[4] Climate Justice Programme (CJP) "Nigerian Gas Flaring Fact Sheet" http://www.climatelaw.org/cases/casedocuments/nigeria/gas-flaring... $\quad$ Retrieved on $13 / 6 / 2012$.

[5] Department of Petroleum Resources, "24\% of Nigerian gas still flared" in the Punch Newspaper, htt://www.punching.com/business/24-of-nigeriangas-stil-flared-dpr/ retrieved on 13/6/2012.

[6] Environmental Rights Action/Climate Justice Programme (June 2005). Gas Flaring in Nigeria: A Human Rights, Environmental Economic Monstrosity, Amsterdam. The booklet could be found at both www.climatelaw.orga and www.eraction.org Retrieved $13 / 6 / 2012$.

[7] Ito, E.E. \& Ugbome I.L. (2017). Impact of gas flaring on biodiversity in Niger Delta, Nigeria. Nigerian Journal of Science and Environment, 15 (1), 147-154.

[8] Justice in Nigeria Now (April 2010)."Gas Flaring in Nige ria: An Overview", www.justiceinnigerianow.org.

[9] New York Times, February 29, 2000. Cited by Rourke J.T. (2007).

[10] Nigerian National Petroleum Corporation, NNPC, (21 May 2012) “Nigeria: Gas Flaring Drops to 14 per cent, says http://allafrica.com/stories/201205210950.htm Retrieved 8/6/2012.

[11] Nii, N. (2015). National Energy Policy and Gas Flaring In Nigeria. Journal of Environment and Earth Science, 5(14), 58-64.
[12] Odionu, G. (2018). Mitigation of greenhouse gas emissions from gas flaring in Nigeria: Perspectives on law and regulation. A thesis submitted to the college of graduate and postdoctoral studies, in partial fulfilment of the requirements for the Degree of Master of Laws (LLM) in the College of Law, University of Saskatchewan, Saskatoon, Canada.

[13] Olufemi, F. J. \& Samson, A. O. (2012).Climate Change, Environment and Conflicts in Nigeria, British Journal of Arts and Social Sciences, 6(1), http://www.bjournal.co.uk/BJASS.aspx.

[14] Shehu, K., Auwal, I. N. \& Dahuwa, A. A. (2018). A Review of Climate Change: Its Impacts and Governance for Enhancing Nigeria's Environmental Resources. Dutse Journal of Pure and Applied Sciences, 4(2): 77-86,

[15] The World Bank (1995). Defining and Environmental Development Strategy for the Niger Delta. Volume 1 (Report No 14266-UNI).

[16] Urim, U. M., Imhonopi, D., \& Egharevba, M. E. (2013). Advancing solutions for climate change in Nigeria: An appraisal. In D. Imhonopi \& U. M. Urim (Eds), A panoply of readings in social sciences: Lessons for and from Nigeria. Pp. 233-247. Lagos: Department of Sociology, Covenant University, Ota, Ogun State.

[17] Wikipedia (2007). "Gas Flare", http://en.wikipedia.org/wikigasflare. Retrieved June 4th, 2012.

[18] Wikipedia "Gas (2011). Flare", http://en.wikipedia.org/wikigasflare. Retrieved June, 9th 2012. 